\title{
AN INNOVATIVE STEERING SYSTEM FOR A RIVER PUSH BARGE OPERATED IN ENVIRONMENTALLY SENSITIVE AREAS
}

\author{
Teresa Abramowicz-Gerigk \\ Gdynia Maritime University, Faculty of Navigation, Department of Ship Operation \\ Zbigniew Burciu \\ Gdynia Maritime University, Faculty of Navigation, Department of Ship Operation \\ Jacek Jachowski \\ Gdynia Maritime University, Faculty of Navigation, Department of Ship Operation
}

\begin{abstract}
The paper presents an innovative steering system for a river push barge dedicated for operation in environmentally sensitive inland waterways. Development of the inland waterborne transport in Poland is dependent on the exploitation of rivers which can be adapted to navigation in the limited range because a high percent of their length is classified within special environment protection areas of Natura 2000 network. This is now the main reason that their better exploitation cannot be obtained without an introduction of a new generation of waterborne environment friendly inland units. In naturally winding rivers with differing and rapidly changing depths and widths it is important to equip a push barge with an efficient steering system that has a low environmental impact. The innovative steering system proposed in the paper is composed of main steering devices located at the pusher stern, auxiliary steering devices installed on the barge bow and a mechanical coupling system.
\end{abstract}

Keywords: river push barge, manoeuvring area, bow rotor, integrated steering system

\section{INTRODUCTION}

The development of sustainable inland waterborne transport (IWT) covers the improvement of the complex framework of inland navigation, hydraulic engineering and protection of natural environment. Many years of negligence in river training and maintenance are the reasons that a big part of inland waterways has become wildlife areas. The main bottle necks in inland navigation on Polish rivers are the restricted water depth, different flow rates at different water levels; restricted fairway width on river bends and the Natura 2000 special environment protection areas located along the rivers.

The areas length within the Natura 2000 network as a percent of the total river length for Odra and Vistula are
$73.46 \%$ and $30.86 \%$ respectively [5]. All the factors influencing environmental impact of inland shipping in special protection areas should be considered along with the natural river processes which can increase or decrease the influence of ship traffic.

Polish rivers can be adapted for navigation in limited range and their better exploitation can be obtained mainly by the introduction of a new generation of waterborne inland units along with integrated traffic management and logistic systems $[2,14]$. The regular navigation can decrease the amount of required maintenance works - dredging, winter ice-breaking and support flood protection.

In Poland the most important issue is now IWT on Lower Vistula River due to untapped transport potential [2]. The innovative solutions in IWT will be developed 
and implemented on the market i.e. within the frames of the research and development projects included in "The Lower Vistula" horizontal project venture within "Smart Specialisation of Pomerania Region - offshore technology, ports and logistics" Regional Operational Programme for the Pomeranian Voivodeship for the period 2014-2020.

The first project is "Research, design and construction of a prototype of an innovative push train: pusher with hybrid propulsion with innovative ship's boat with changing draft and fuel cells power supply, innovative pushed barge for heavy oversized goods transport with an anti-heeling system for ro-ro operations and bow thruster (with dimensions matched the Przegalina lock)".

The priorities formulated in the resolution "Assumptions for the plans of inland waterways development in Poland in the years 2016-2020 with the 2030 perspective" [6] included i.e. development and implementation of E-30 waterway into the international waterways network, improvement of navigational conditions on the Vistula River, preparation for the modernization of E-40 and E-70 waterways and implementation of RIS (River Information System). The Vistula River Warsaw-Gdansk section will become an international waterway until 2030. After the first stage of modernization of the Lower Vistula the transport of goods is expected to reach the level $7.8-12 \mathrm{mln}$ tonnes/year [16]. The fast growth of the handling capacity of the container terminals in Ports of Gdansk and Gdynia can speed up this process. The oversized heavy goods transport is the main demand for the Middle and Lower Vistula River IWT at the moment.

The investigations presented in the paper were conducted in order to define possibilities of handling a pushed barge train on natural rivers and obtain an early estimate of the manoeuvrability of the river push barge equipped with bow rudders.

\section{RIVER BARGE TRAINS OPERATED IN THE MIDDLE AND LOWER VISTULA RIVER}

The maximum dimensions of vessels and pushed convoys which may be accommodated are length, breadth, draft. These are dependent on river parameters and air draft depends on height of the space under bridges. All sections of the Lower Vistula River are classified as free flowing. The section from Bydgoszcz to Wloclawek $(772.4 \mathrm{~km}-674.8 \mathrm{~km})$ requires the lowest values of ship draft - about $0.8 \mathrm{~m}$, depending on the water level (LWL - Low Water Level) [7].

Tab.1. The main dimensions of locks on Gdansk - Warszawa section of E-40 waterway

\begin{tabular}{|c|c|c|}
\hline Lock & Przegalina & Wloclawek \\
\hline Length $[\mathrm{m}]$ & 188.37 & 115.00 \\
\hline Width $[\mathrm{m}]$ & 11.91 & 12.00 \\
\hline Depth at sills $[\mathrm{m}]$ & $3.60 / 3.28 \mathrm{LWL}$ & 3.50 \\
\hline
\end{tabular}

Barge train formations operated on the Middle and Lower Vistula River are different combinations of pushing-towing units. The main dimensions of the barges operated in these pushing-towing units, described by Rabant et al. [15] are presented in table 2 .

Tab. 2. Main dimensions of the barges used in pushing-towing units on the Lower Vistula River

\begin{tabular}{|c|c|c|c|c|}
\hline \multirow[b]{2}{*}{ Main dimensions } & \multicolumn{4}{|c|}{ Barge type } \\
\hline & 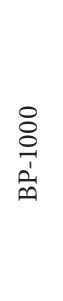 & 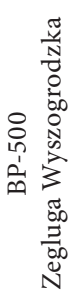 & 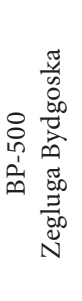 & 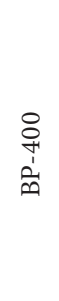 \\
\hline Length [m] & 73.0 & 56.0 & 44.0 & 35.0 \\
\hline Breadth $[\mathrm{m}]$ & 10.2 & 10.2 & 8.0 & 8.5 \\
\hline Draft [m] & 0.9 & 0.9 & 0.9 & 0.7 \\
\hline
\end{tabular}

A predominantly used push barge consists of a pusher and barge with couplings made of cable ropes, winches and hydraulic cylinders with the coupling force $800-1200 \mathrm{kN}$. An example of the coupling used for the container push barge on the Lower Vistula River in April 2017 [9] is presented in figure 1 .

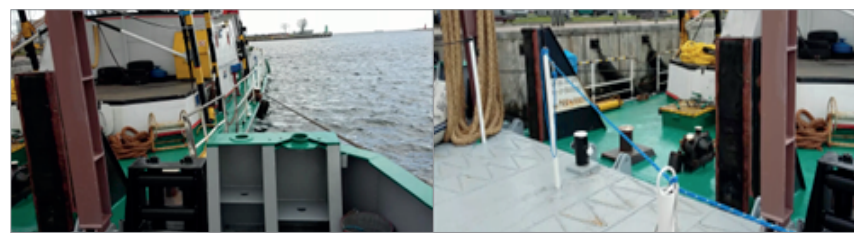

Fig. 1. Push barge - pusher boat "Hetman" and barge "Galar-2" coupling system including cable lines and hydraulic cylinders, on the Lower Vistula River in April 2017

The operability of a new design environment friendly push barge depends on its good propulsive and manoeuvring properties both in shallow and deep water conditions. The push barge should generate waves of acceptable significance to reduce the influence on river banks, and low velocity propeller thrust streams to avoid river-bed scouring.

In naturally winding rivers with differing and rapidly changing depths and widths it is important to equip a push barge with an efficient steering system having low environmental impact.

\section{THE INNOVATIVE PUSH BARGE BOW STEERING SYSTEM}

The innovative steering system proposed in the paper is composed of auxiliary steering devices installed on the barge 
bow, dynamic coupling system and main steering devices located at the pusher stern.

\section{BOW ROTORS AUXILIARY STEERING DEVICE}

The conventional auxiliary steering devices are mainly bow thrusters. They produce high velocity thrust streams and their efficiency drops sharply at ship speed above $2 \mathrm{~m} / \mathrm{s}$ in open water conditions (Fig. 2).

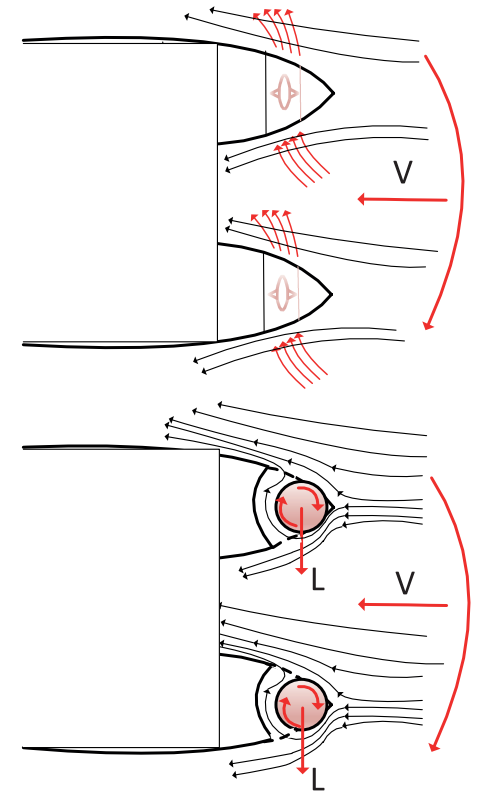

Fig. 2. Effects of barge bow steering systems: 1 - bow thrusters; 2 - bow rotors, $v$ - inflow speed, L - hydrodynamic lift force [3]

The rotor bow rudder system based on the Magnus effect results in a significant enhancement in manoeuvrability. The rotating cylinder in oncoming water currents produces a lift force larger than a conventional rudder.

The most effective operational configuration without the ventilation effects influence is the configuration with the rotor extruded below the bow. The existing vertical and retractable versions of rotor bow rudder $[10,20]$ are not suitable for shallow water conditions, therefore the steering system of rotors integrated with the barge bow has been proposed.

\section{RESISTANCE OF A PUSH BARGE WITH DIFFERENT CONFIGURATIONS OF BOW ROTORS}

Barges with vertical or slightly inclined stems have greater resistance than the streamlined forms $[12,18]$, however at this stage of investigations, the simple straight inclined bow which could be modified to test different configurations of bow rotors has been assumed.

To determine the ship manoeuvring performance the existed IMO criteria based on the standard trials are used in general. The criteria are not designed specifically for pusherbarge or tug-barge formations and the assumptions should be made regarding the method of their application. Liu et al. [13] proposed the standard maneuvers and parameters for the evaluation of inland push barge maneuverability. The length of the ship originally defined as the length measured between perpendiculars was assumed for the pusher-barge combination as the distance measured between the aft perpendicular of the pusher and the forward perpendicular of the barge.

The resistance of the barge with straight inclined bow without rotors has been compared with the resistance of the barge with central bow skeg with rotor, twin bow skegs with rotors, twin cylindrical bulbs without and with rotors. The hull forms of the first three configurations and their resistance predicted using CFD FlowVision solver [22] at $10 \mathrm{~km} / \mathrm{h}$ speed are presented in figures 3-6. The main particulars of the push barge model are presented in table 3.

Tab. 3. Main dimensions of the push barge model used in CFD simulation for resistance prediction

\begin{tabular}{|c|c|c|}
\hline Dimension & Push barge model & Push barge \\
\hline Length [m] & 4.966 & 100 \\
\hline Breadth [m] & 0.55 & 11 \\
\hline Draft [m] & 0.06 & 1.2 \\
\hline Buoyancy [kg] & 160 & 1280000 \\
\hline Model scale & $1: 20$ & $1: 1$ \\
\hline
\end{tabular}

The 3-dimensional CFD flow simulations were performed in full scale, based on the reverse flow method using overlapping meshes. The VOF method in the free surface modelling and semi-empirical $k-\varepsilon$ turbulence model were applied.

For the purpose of the simulation the calculations were carried out in the domain of discretized structural mesh consisting of 1.4 million cells.
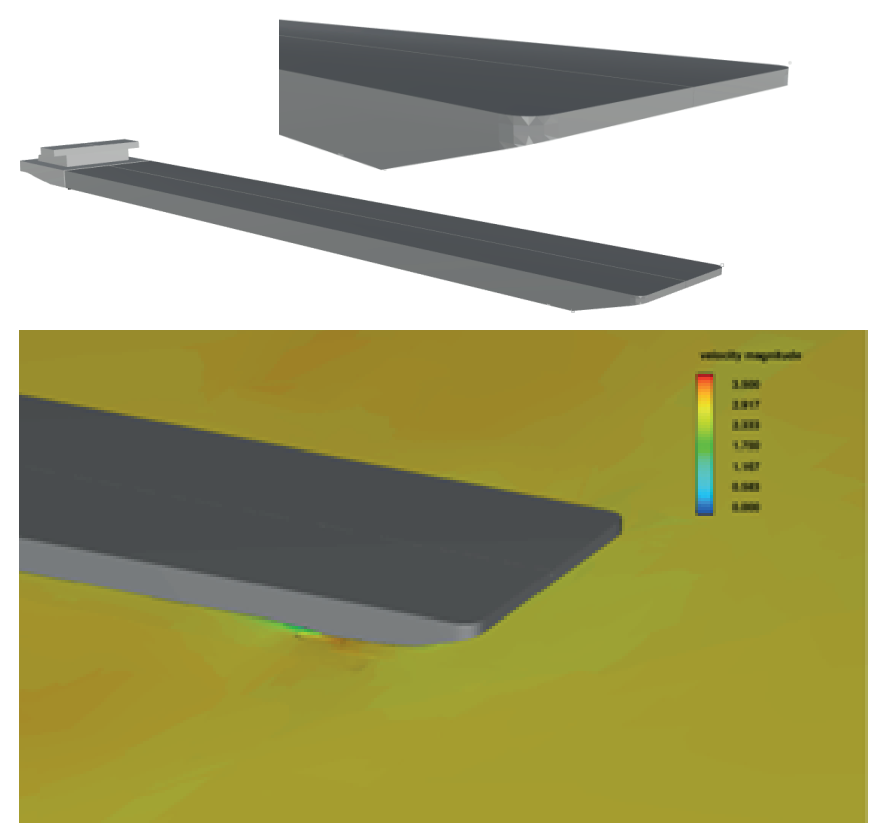

Fig. 3. Push-barge with a straight inclined bow 

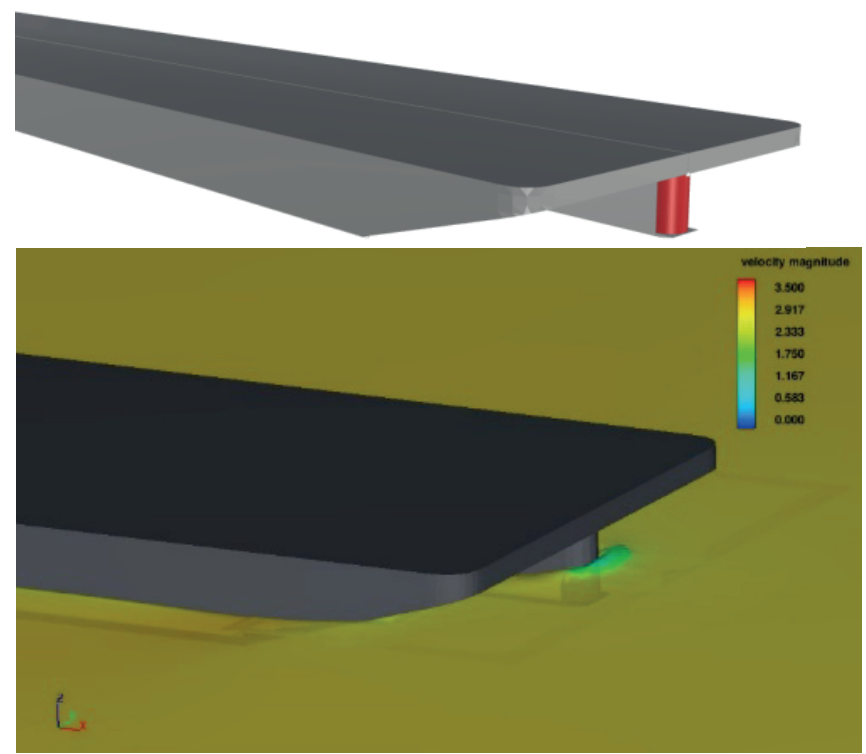

Fig. 4. Push-barge with a central bow skeg and rotor
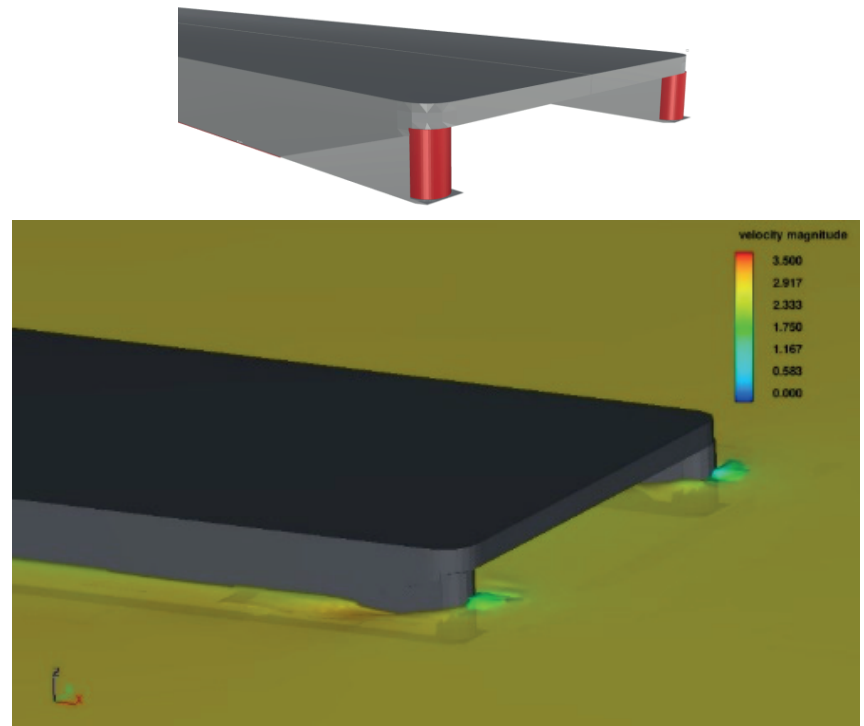

Fig. 5. Push-barge with twin bow skegs and rotors

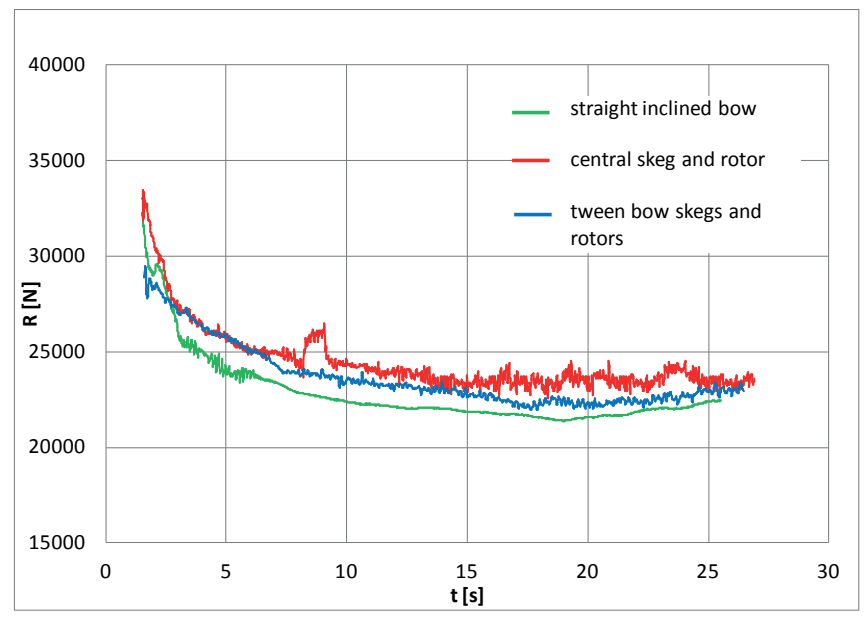

Fig. 6. Resistance of the push barge with different bow configurations at $10 \mathrm{~km} / \mathrm{h}$ speed: $R$ - resistance, $t$ - time of simulation
The twin bow rotors integrated with cylindrical bulbs give much smaller steering force and almost the same resistance in shallow water (Fig. 7). This observation suggests that the favourable configuration from the point of view of push barge hull resistance is the bow with twin bow skegs and rotors.

The resistances at $15 \mathrm{~km} / \mathrm{h}$ in $5 \mathrm{~m}$ shallow water at 0.6 critical speed assumed as square root of the product of water depth and ship speed are presented in figure 7.

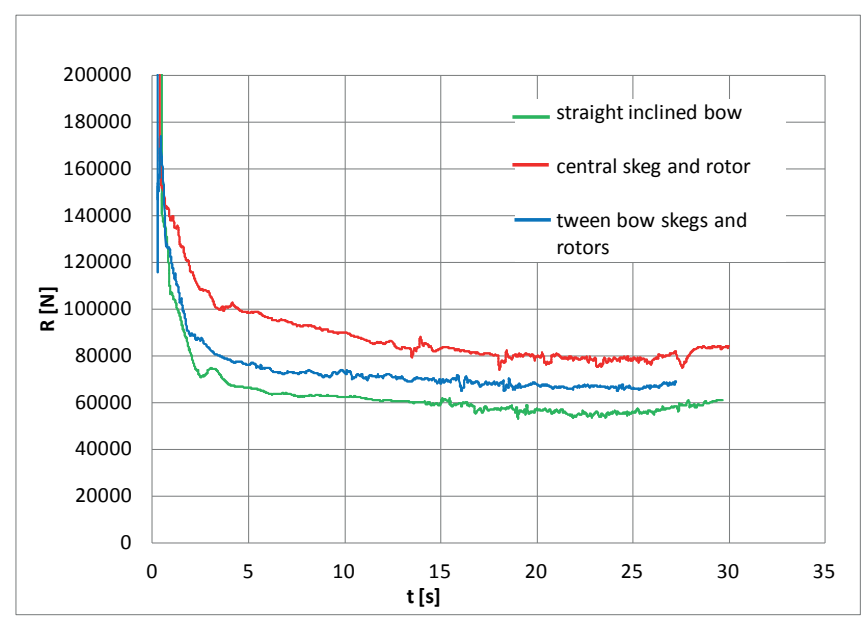

Fig.7. Resistances of the push barge with different bow configurations at $15 \mathrm{~km} / \mathrm{h}$ speed: $R$ - resistance, $t$ - time of simulation

\section{TURNING ABILITY OF PUSH BARGE WITH BOW ROTORS}

The results of experiments presented in the literature [19] show a significant decrease of the lift coefficient of a steadily rotating rotor due to the wake separation. The numerical investigations and model tests of the proposed rotor bow steering system confirm the conclusions from the previous research.

The results of CFD simulations of rotor with $1 \mathrm{~m}$ diameter and aspect ratio of 1 performance at $5.55 \mathrm{~m} / \mathrm{s}$ inflow speed are presented in figures 8-11. The flow field for the motionless cylinder is presented in figure 8 . The flow field for the cylinder rotating with the linear velocity of rotation 4 times greater than the inflow speed - in open water conditions, with a front horn (front guard) and integrated with a cylindrical bulb are presented in figures 9, 10 and 11 respectively.

The lift force of a steadily rotating rotor in open water conditions is very small due to the wake separation and ventilation effects. In the case of rotor integrated with the bow cylindrical bulb the opposite sign of a lift force was observed. 


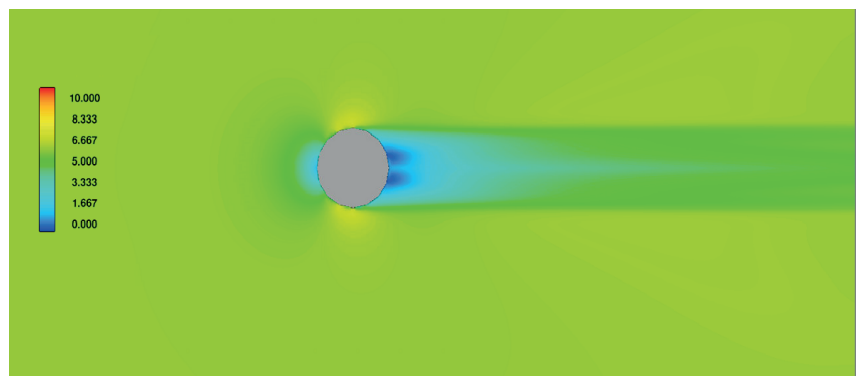

Fig. 8. CFD simulation of rotor performance: flow field around the motionless cylinder

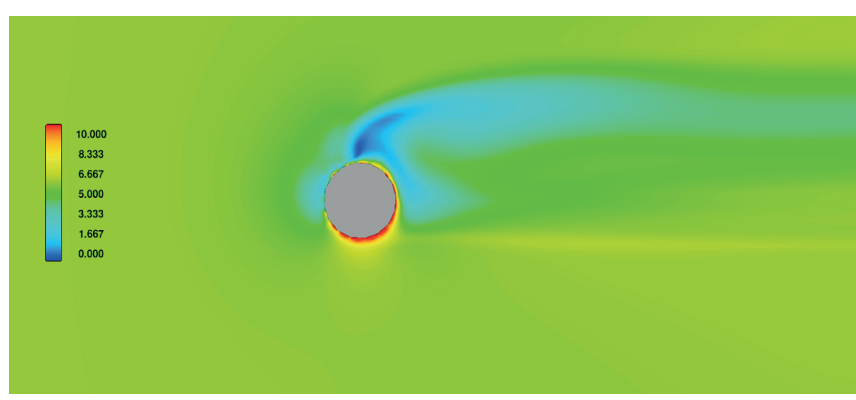

Fig. 9. CFD simulation of rotor performance: flow field around a rotor at the linear velocity of rotation 4 times greater than the inflow speed in open water conditions

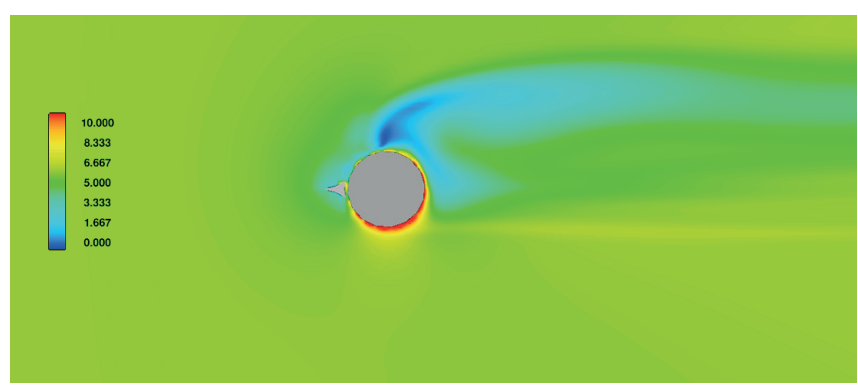

Fig. 10. CFD simulation of rotor performance: flow field around a rotor with a front guard at the linear velocity of rotation 4 times greater than the inflow speed in open water conditions

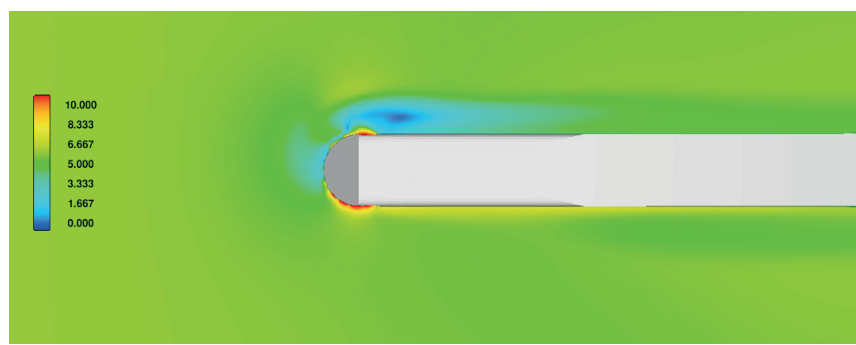

Fig. 11. CFD simulation of performance of a rotor integrated with a cylindrical bulb: flow field around the rotor at the linear velocity of rotation 4 times greater than the inflow speed

The lift forces generated on the rotor for the above cases are presented in figure 12.

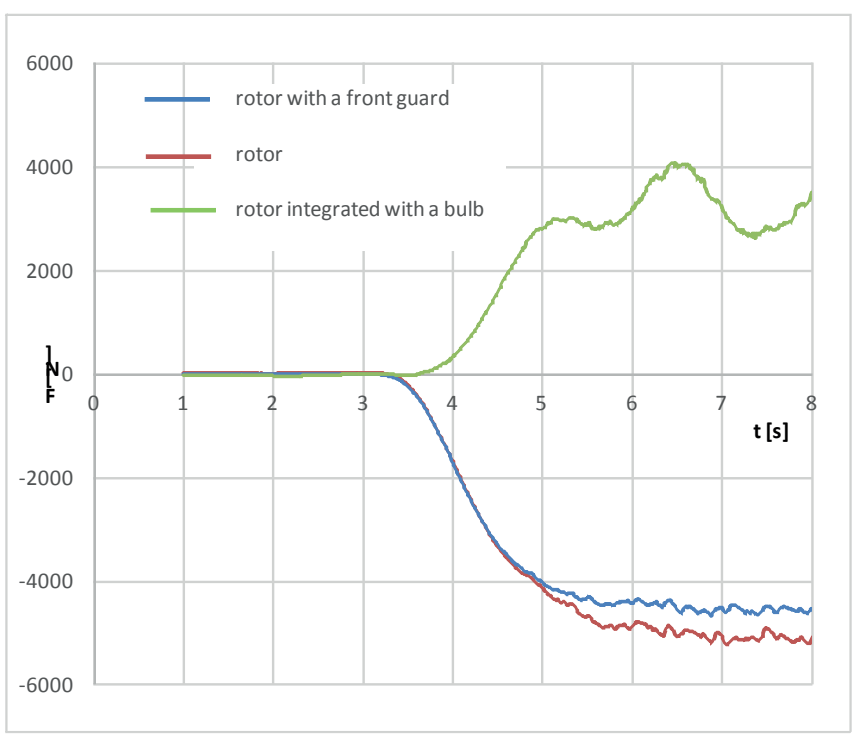

Fig. 12. CFD calculation of the lift force generated on the rotors in different configurations: F - lift force, $t$ - time

The phenomena were discussed in [19] and they were confirmed by physical model tests, where the unsteady effects significantly increased the observed lift force.

During the early stage of the concept study the test of turning ability was crucial to ensure the possibility to handle the push barge using bow rotors. At this stage the tests were conducted with an arbitrary hull form representative for pushers and barges under consideration with the main particulars presented in table 3 assumed in CFD simulation

A pusher model was equipped with twin rudders and twin fixed pitch propellers with $0.04 \mathrm{~m}$ diameter and $8000 \mathrm{rpm}$ rotational speed each. The main engine power of the pusher was $2 \times 150 \mathrm{~kW}$.

The physical model of the push barge is presented in figure 13.

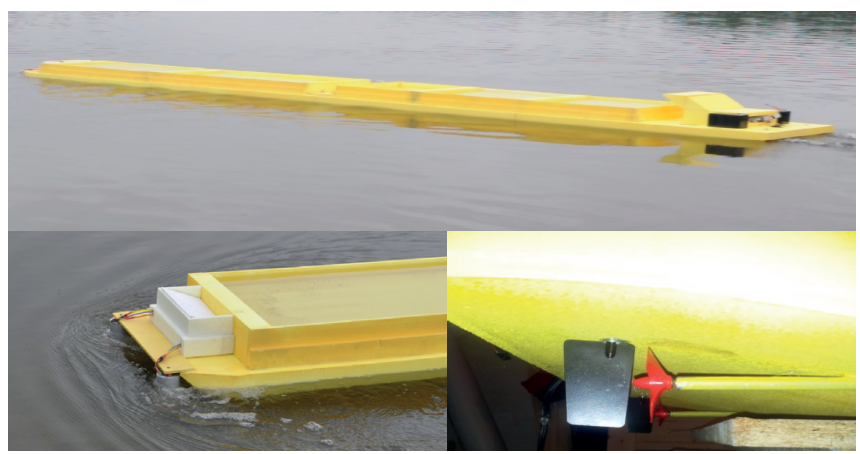

Fig. 13. Physical model of the push barge

The example of a turning trial using only bow rotors steering system at the initial speed $0.5 \mathrm{~m} / \mathrm{s}$ is presented in figure 14 . 


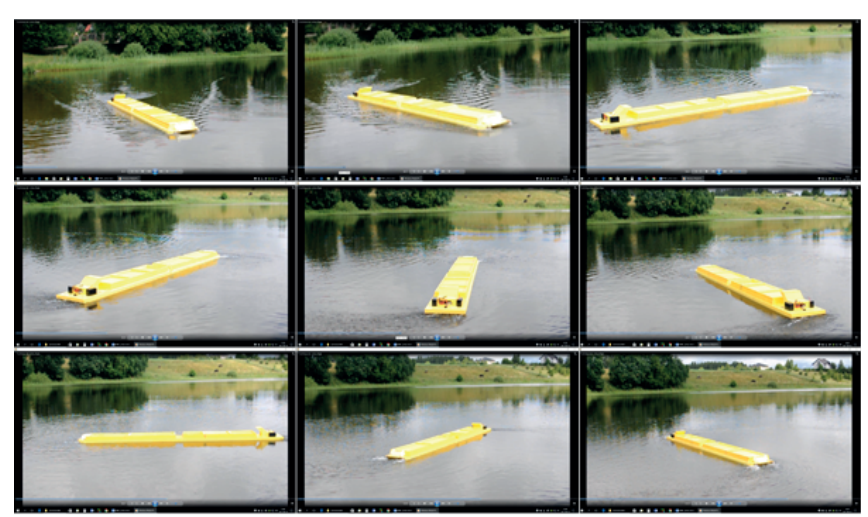

Fig. 14. Turning circle manoeuvre using bow steering unit

The push barge initially starts turning immediately after the rotors start to rotate. The lift force generated by the bow rotors in the second phase of circulation, when the push barge has changed its heading gets the longitudinal stopping component, resulting in tight turn due to the transfer of the pivot point astern and decrease of push barge speed. Then the rotors steering force drops due to the small inflow speed, the barge stops turning and then after the lift force increases it starts a very tight turn again. The tighter turning was observed when both the coupled twin rudders and bow steering system were used simultaneously.

To determine the manoeuvring performance the qualitative investigations on turning and yaw-checking abilities of the push barge should be followed by detail measurements.

\section{PUSHER-BARGE COUPLING}

The pushing system has an impact on the operational efficiency and safety of a push barge. It has an influence on the running speed and time needed for berthing, unberthing and exchanging barges. In sheltered, wide waters simple methods of mechanical connection using wire ropes winches and hydraulic cylinders can be applied to assure satisfactory performance. The rope-connection is rigid, mechanically locked and has an absolute limit in the horizontal plane.

The mechanically connected pusher-barge combination can be designed and constructed for unrestricted service $[21,17]$. The proposed coupling system presented in figure 15 incorporates the use of a steering mechanism secured between a pusher and a barge for the purpose of pivoting the barge with respect to the pusher. It gives the possibility to control relative movements of the pusher and barge in horizontal plane and increases the manoeuvrability performance of the formation.
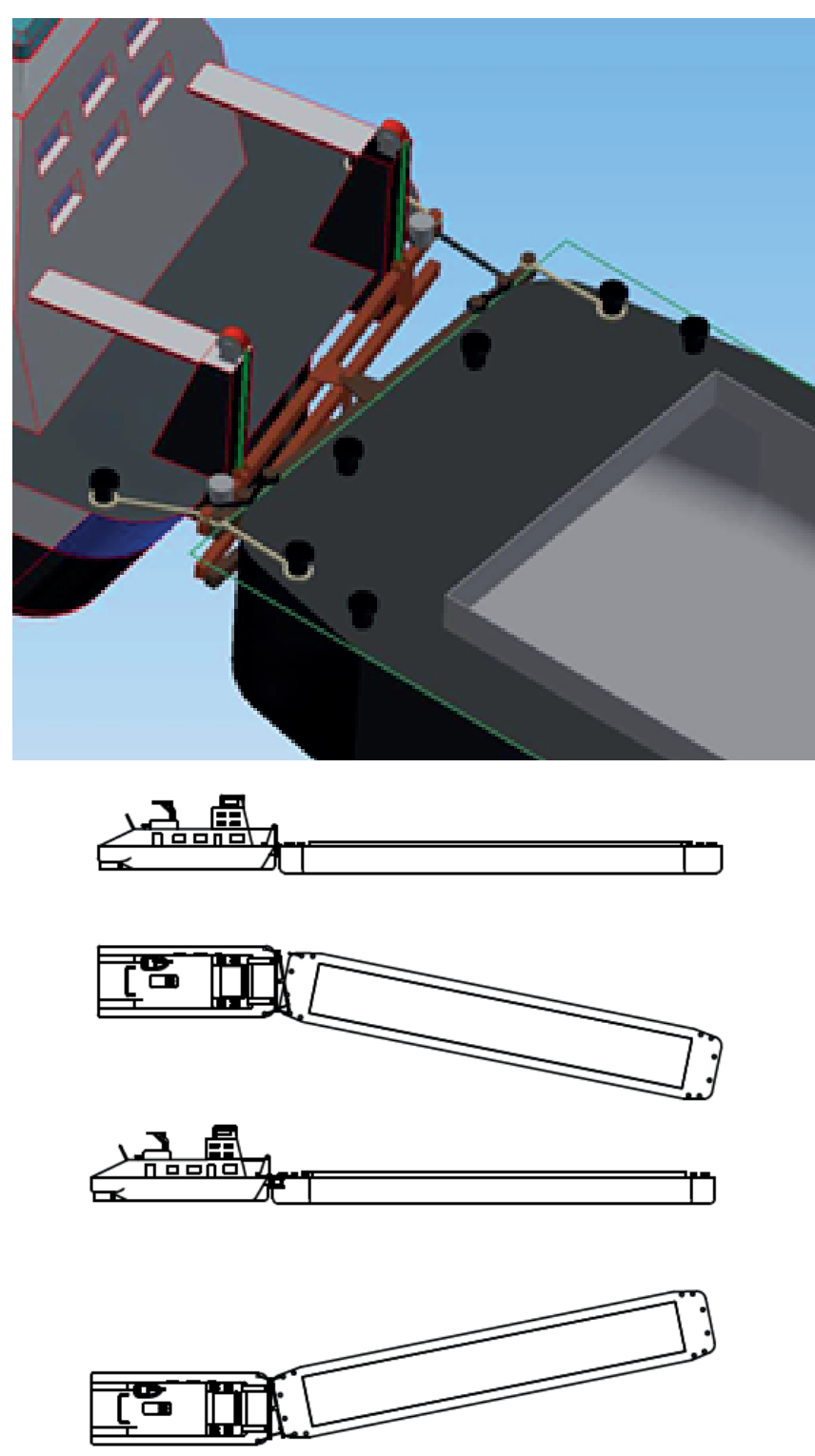

Fig. 15. Coupling system for a waterborne inland barge [4]

Effective steering depends on a reliable hydrodynamic model of the push barge motions and an integrated handling system including the mechanical coupling and steering devices both at the bow and at the aft. The system is now under development within the $\mathrm{R} \& \mathrm{D}$ project R.P.P.M.01.01.01-22-0075/16-00.

\section{CONCLUSIONS}

The preliminary study concerning the manoeuvrability of the concept push barge was divided into a CFD study phase and a model test phase. The results showed a big potential of the innovative steering system that includes a mechanical coupling system and bow rotors.

The different manoeuvring performance of the push barge needs to be further investigated for the optimal use of bow 
rotors and the steering system. The most important issues are the tight turns at different speeds and pivot turns performed at slow speeds.

The proposed bow rotors system has much less influence on the river bed than bow thrusters. It has much less influence on small boats in narrow passages and canals than bow thrusters. The presented push barge is a promising innovation in terms of the economic and ecological potential for the inland waterway sector.

\section{ACKNOWLEDGEMENT}

The research presented in this paper has been financially supported by the Regional Operational Programme for the Pomeranian Voivodeship for the period 2014-2020: "Smart Specialisation of Pomerania Region program - offshore technology, ports and logistics"; within the frames of the R\&D project: R.P.P.M.01.01.01-22-0075/16-00 "Research, design and construction of a prototype of an innovative push train: pusher with hybrid propulsion with innovative ship's boat with changing draft and fuel cells power supply, innovative pushed barge for heavy oversized goods transport with an anti-heeling system for ro-ro operations and bow thruster (with dimensions matching the Przegalina lock)".

\section{BIBLIOGRAPHY}

1. Abramowicz-Gerigk T., Błachuta J., Burciu Z., Granatowicz J., Jacyna M., Kulczyk J., Mazurek M., Nowakowski T., Picińska-Fałtynowicz J., Skupień E., Tubis A., WerbińskaWojciechowska S., Więckowska M., Winter J. WP5 of European project INVAPO "Upgrading of Inland Waterway and Sea Ports" - coordinated by Gdynia Maritime University, Gdynia 2014.

2. Abramowicz-Gerigk T., Burciu Z. 2016. The influence of regular river navigation in special protection areas of NATURA 2000 Network. Journal of KONES. Vol. 23 No. pp 9-16.

3. Abramowicz-Gerigk T., Burciu Z., Krata P. "Steering system for a waterborne inland unit "Patent application P. 420664. 2017

4. Abramowicz-Gerigk T., Burciu Z. Stefurak W. Coupling system of a pusher and waterborne barge. Patent application P. 420684. 2017

5. Assessment of plans and projects significantly affecting Natura 2000 sites Methodological guidance on the provisions of Article 6(3) and (4) of the Habitats Directive 92/43/EEC. http://ec.europa.eu/environment/nature/natura2000/ management/docs/art6/natura_2000_assess_en.pdf

6. Assumptions for the plans of inland waterways development in Poland in 201602020 with the perspective to 2030. Ministry of Maritime Economy and Inland Navigation. Document accepted by the Council of Ministers 14 June 2016.

7. "Blue Book". Second draft of the Inventory of Main Standards and Parameters of the E Waterway Network ("Blue Book"), 2016. Third revision Working Party on the Standardization of Technical and Safety Requirements in Inland Navigation Forty-ninth session, Geneva, 22-24 June 2016. Item 5 (b) of the provisional agenda Inland waterways infrastructure. https://www.nece.org/fileadmin/DAM/trans/doc/2016/ sc3wp3/ECE-TRANS-SC3-WP3-2016-inf_30e.pdf

8. Burciu Z., Gąsior A. 2015. The analysis of the possibility of revitalization of the Lower Vistula river based on INWAPO European Project. Scientic Journals of Gdynia Maritime University No. 92/2015, in Polish.

9. EMMA - Enhancing freight Mobility and logistics in the BSR by strengthening inland waterway and river sea transport and promoting new international shipping services - project funded by the Interreg Baltic Sea Region Programme 2014-2020.

10. Keuning F. W. Motion control of small fast boats in following waves. SNAME Symposia Papers. 2016. http://www. sname. org/HigherLogic/System/DownloadDocumentFile. ashx?DocumentFileKey=ef3cb5a3-350b-e385-d7a2a91fddd0589a.

11. King K. K., Yasukawa H., Hirata N., Kose K. Manoeuvring simulations of pusher-barge systems. Journal of Marine Science and Technology, 2008, Volume 13, Issue 2 pp. 117-126.

12. Kulczyk J., Werszko R. Influence of ship motion on waterway backward current velocity. Polish Maritime Research, Special Issue 2006/S2.

13. Liu J., Hekkenberg R., Rotteveel E. A Proposal for Standard Manoeuvres and Parameters for the Evaluation of Inland Ship Manoeuvrability. European Inland Waterway Navigation Conference 2014, Budapest, Hungary.

14. PIANC Report N 99. 2008. Considerations to reduce environmental impacts of vessels navigation. Inland Navigation Commission. www.pianc.org.

15. Rabant H., Habel M., Babiński Z. Transport of the oversized goods on the Vistula waterway. The basic waterway parameters and main difficulties. Works of Commission Of Communication Geography PTG 2016, 19(3), pp. 7-17, in Polish.

16. Resolution on acceptance of "Assumptions for the plans of inland waterways development in Poland in 201602020 with the perspective to 2030". https://www.premier.gov. $\mathrm{pl}$ / wyda rzenia/decyzje-rzadu/uchwala-w-sprawie-przy 
jecia-zalozen-do-planow-rozwoju-srodladowyc h-drog. html.

17. Smith W. J. 1959. Steering connection between a barge and a pusher tug. US Patent 3035537 A

18. Tabaczek T., Kulczyk J., Zawislak M. Analysis of hull resistance of pushed barges in shallow water. Polish Maritime Research 1(51) 2007, Vol 14, pp. 10-15

19. Tokumaru T., Dimotakis P. E. The lift of a cylinder executing rotary motions in a uniform flow. J. Fluid Mech. (1993), vol. 255, pp. 1-10

20. http://www.vdvelden.com/products/product/rotor-bowrudder.html

21. http://www.articouple.com/5-articouple_fr.html

22. http://www. fv-tech.com

\section{CONTACT WITH THE AUTHORS}

\section{Zbigniew Burciu}

e-mail:zbj@am.gdynia.pl Gdynia Maritime University Morska, 81-225 Gdynia

Poland

\section{Teresa Abramowicz-Gerigk}

e-mail: tagerigk@am.gdynia.pl Gdynia Maritime University Morska, 81-225 Gdynia

Poland

\section{Jacek Jachowski}

e-mail:jj@o2.pl

Gdynia Maritime University Morska, 81-225 Gdynia

Poland 